\title{
Article \\ In the Shadow of Bell Towers: The Use of Religious Capital among Christian-Catholic Second Generations in Italy
}

\author{
Roberta Ricucci \\ Department of Culture, Politics and Culture, University of Turin, 10153 Turin, Italy; E-Mail: roberta.ricucci@unito.it
}

Submitted: 30 October 2015 | Accepted: 19 December 2016 | Published: 19 April 2016

\begin{abstract}
Evidence from some contemporary ethnic groups suggests that ethnic religion may play a strong role in the lives of second generation members. This is evident in recent studies on Muslims living in Europe. But Europe's immigrant population is not just Muslim in origin. Migratory flows from Latin America, the Philippines and Eastern Europe (i.e. Romania or Ukraine) bring people from Catholic and Christian countries to Europe. And-as in the Italian case-these groups are now the majority among the whole immigrant population. Consequently, the almost exclusive focus on the Islamic component has allowed little investigation of the increase of the Christian-Catholic component. The paper describes and compares the religious paths of immigrants' youth from Peru, the Philippines and Romania, considering the following questions: How do they interact with/develop their religious identity? Is this generation seeking less visible, less participatory means of contact with the church to better integrate with their peers? Or, on the contrary, do they choose, strategically, to reinforce the Catholic part of their identity in order to succeed better in the integration process in a Catholic country?
\end{abstract}

\section{Keywords}

Christian-Catholic; discrimination; identity; immigrants; Italy; religion; second generation

\section{Issue}

This article is part of the issue "Religious Diversity and Social Inclusion", edited by Gary Bouma (Monash University, Australia).

(C) 2016 by the author; licensee Cogitatio (Lisbon, Portugal). This article is licensed under a Creative Commons Attribution 4.0 International License (CC BY).

\section{Introduction}

The question of how faith, ethnicity and acculturation relate to one another is highly pertinent in the Italian context, where Catholicism continues to be the religion of reference for the majority of the population in spite of the secularization process of other European countries (Garelli, 2013; Marzano \& Pace, 2013; PérezAgote, 2012). Around five million migrants were registered at the beginning of 2014 (ISTAT, 2015) in Italy, which outlines a complex situation, characterized by immigrant flows from more than 191 countries, especially Central and Eastern Europe, Northern Africa, Latin America and South-East Asia. The presence of immigrant minors in Italy has by now been an established fact of life for at least 15 years, highlighting the stabilizing character of migratory flows towards the country: a rapid evolution which had affected first schools and then the whole society (Vilaça \& Pace, 2010). In this scenario, Christian-Catholic second generations are increasing in numbers and visibility. So far, from the religious point of view, the Italian scenario has deeply changed after the considerable Eastern European migration flows. Romanians, Ukrainians and Poles have modified the religious composition in the migrant population. Even if the media sometimes continue to stress the risk of Islamization (Allievi, 2009), it is incorrect to speak of an "Islamic invasion", first of all because of the statistics: according to estimates by the Italian National Office Against Racial Discrimination (UNAR), Christians constitute $52 \%$ of immigrants and Muslims 32\% (UNAR, 2015).

In this context, I applied my research on three Christian-Catholic immigrant groups which are repre- 
sentatives of the great majority of non-Muslim immigrant population in Italian, as well as in Europe. I carried out qualitative research in order to investigate how religion and integration paths interact with and influence one another, both on the societal and on the individual levels in the case of Christian-Catholic second generations in a specific context like Italy, a recent immigration country and a Catholic one, considering the following questions: How do they interact with/develop their religious identity? Are they followers of the "traditional religiosity" of their parents (the first generation) or do they belong to the "secularised millennium generation"? Are they looking for a different (from their Italian peers) relationship with religion, more spiritual, requiring regular meetings, or do they want to get away from this? Are this generation seeking informatics religious tools and means of contact with the church, less visible and "non-inserted" in the integration process among peers? Or, on the contrary, do they choose, strategically, to reinforce the Catholic part of their identity in order to succeed better in the integration process in a Catholic country?

In order to answer my research questions, I focused my attention on three specific youth groups: Filipinos, Peruvians and Romanians.

My thesis is, on the one hand, that these young people (that enjoy a good reputation among Italians) who-formally-haven't negotiated their religious identities at school or in the broader society due to their Christian-Catholic adherence can easily maintain a strong religiousness. On the other, they are "children of their time" and they share with their peers (Italians as well as those who belong to other nationalities) the idea of leaving religion and returning just for family reasons or for special events. Paradoxically, these young people are going to develop (maybe similarly to their Muslim peers, even though for different reasons) and "amphibian strategy": e.g. as their Moroccan peers, Filipinos "choose, paradoxically, the same strategy because they do not want to be rejected by their Italian peers who don't attend church, do not spend their free time in religious associations, and don't share their values of filial piety, respect for parents, and family centeredness" (Ricucci, 2010).

The paper uses qualitative research data collected in the Italian context: it is of course a peculiar case due to its religious characteristics but findings can offer interesting and generalizable consideration for research on the relationship between second generations and religion in Europe.

\section{Methodology}

Thanks to the qualitative approach, the paper presents a complex scenario in which assimilation tensions are mixed with identity cleavages, individuating how Christian-Catholic second generations are changing common perceptions of the relations between religion and immigration. Here, the perspective I assumed is that there are many possible patterns in the relationship with religion among Christian-Catholic young people (as well as their Muslim and Italian peers) and the outcomes depend on three sets of factors: a) Personal and demographic factors (e.g. gender, age, length of residence); b) factors that are external to individuals and their communities (policies towards diversity in the society); and c) Differences between immigrant groups and society at large (such as differences in values).

This paper presents a part of the findings collected during a fieldwork study (carried out along the last four years) that allowed me to explore the social and religious experiences of three specific youth groups (Peruvians, Romanians and Filipinos) with migratory backgrounds behind and beyond their faith communities. Specifically the qualitative sample is composed of 75 interviews ${ }^{1}$ with young people ${ }^{2}$, aged $18-29$, speaking Italian, gender balanced and equally distributed among the three immigrant sub-groups: Peruvians, Romanians and Filipinos, that I'm going to describe briefly.

Filipinos-particularly women-were the first to arrive. Today the community is numerous with a high incidence of family reunion, adolescents and young people who received the call to Italy after years of being "children left-behind" (Parrenãs, 2003; Zanfrini \& Asis, 2006). The Peruvian community, on the other hand, began its immigration flow towards the middle of the 1980s. This was also principally female: as with the Filipinos, South American women left first, to be joined later by their children and, possibly, their partners (Caselli, 2008; Paerregaard, 2010).

The Romanians present different characteristics: their migration exploded in the 2000s with a greater balance between the sexes, even if women were in the majority (Cingolani, 2009; Ricci, 2006). In any case the three groups share same characteristics: 1) Relative ease of insertion into the labour market (Betrand \& Mullainathan, 2004); 2) Prevalence of care-giving among the women; 3) Positive acceptance on the part of Italian society; 4) High rate of children left behind and rejoined years later with their families; 4) Positive image of the children in schools. Using an American concept, Italian media, government, and schools as well as the general debate portray Filipinos, Peruvians and Eastern Europeans as the "model minority", contending that ethnic cultural traits predispose them to

\footnotetext{
${ }^{1}$ I used a model of open semi-structured interview around certain issues (e.g. religious belonging, but also education, friendship, relationship with the family of origin and with ethnic and/or religious associations and migration biography). All the collected material has been codified and analyzed with Atlas.ti. 2 To this qualitative material I added 4 interviews with keyinformants and 12 interviews with representatives of first generation involved in ethnic parishes activities.
} 
be financially and educationally successful (Yu, 2006; Yang \& Ebaugh, 2001). These images create borders between these and other immigrant groups. Two phenomena upset this peaceful scene: the fact of young Latino gangs; and racism against Romanians when they are all equally considered as being of Roma origin. These two issues, however, do not erode their positive perceptions among Italians (UNAR, 2015).

For the parents' generation, religion has been a card to play (even strategically) in the dynamics of insertion in the labour market and acceptance: Filipinos and Peruvians have been welcomed, partly because of their Catholic origins; Romanians, whether Orthodox or Catholic, have also benefitted from their unproblematical religious belonging, which does not demand alternative (to the churches) places of prayer, special work timetables to fit in with prayer or diets and ad hoc teaching in schools. The reunited children's generation from these three backgrounds undoubtedly gain from their ethnic-religious identity which does not draw attention to them-as happens with their Muslim peers. This fact, however, does not make them representative examples of religious culture in their home countries, and nor does it immunize them against the effects of the adaptation process implicit in the integration path, including progressive distancing from institutional religion.

\section{Religion Matters: Catholics Cope with Integration Challenges}

The children of immigration too are children of their age from the religious point of view and are therefore fully part of two dynamics the individual-religion relationship is undergoing. The first concerns the persisting belonging of the youngest to their parents' religion, in spite of growing religious pluralism and the advance of the secularization process (Berger, Davie, \& Focas, 2008; Garelli, Guizzardi, \& Pace, 2003; Hervieu-Léger et al., 1992; Tos, Mohler, \& Malnar, 2000). In a broader sense, the Italian situation reveals particular characteristics compared with other European countries: higher average rate of religiosity; faint presence of other denominations; renewed presence of the Church in the public sphere ${ }^{3}$.

Contrary to the expectations of many observers of modernity, we are not witnessing today a falling off from the religious sphere but a different way of belonging to it and expressing it (Bréchon, 2009; Hoge, Dinges, Johnson, \& Gonzales, 2001). And it is in this direction that we find the other dynamic, that of the growth of the individualism of faith. In the field of studies of religiosity, the decline in young people's attendance at Sunday services is generally considered an indicator of the process of individualization of religious faith; faith is more and more a private fact accompa-

\footnotetext{
${ }^{3}$ For details see Garelli (2011).
}

nied by a reduction of participation in parochial life and observance of the Church's teaching on matters of moral and sexual orientation. This aspect, along with religious institutions' difficulty in reading and interpreting the needs of orientation and their answers to advanced modernity, makes Berger's "solitary believer" (1992) topical today, reinforcing what Davie (1994) identifies as "believing without belonging".

Among the Christian group, most of the interviewees say they are Catholic or Orthodox believers: only 5 Romanians said they believed in a superior being, without going into detail. In describing how they live their lives as believers, all of them, more or less directly, referred to their ethnic churches, which, since their arrival in Italy, have been a point of reference. How this point of reference functions, however, changes in time: if at the beginning it is the "place of worship" par excellence, where one reinforces one's identity, it later becomes principally a point of reference with regard to cultural and linguistic environment.

"Why do I come to this church? Well, it's not strictly for religious reasons, but cultural. Part of the reason is to keep some contact with the Filipino community because it's our only source of cultural identity. It's also important to our parents - this is not the most important factor, but one of the important factors. Another thing is that we think about the next generation. Our kids will have the same exposure if we have contact with the Filipino community." (F, Filipina, 20-year-old)

According to another attending member:

"The first thing that attracts people is fellowship, a sense of closeness. It's trying to find a group that's at ease. There is a sense of comfort in being with other Filipinos because there's an understanding in terms of background." (M, Filipino, 22-year-old)

"It's like being part of an extended family. You feel protected, safe. You don't have to justify who you are, what you do, why you came to Italy." (F, Filipina, 20-year-old)

"I feel well when I am in church. I think of my grandmother at home and get a little homesick. She and I often went to church together. Here I can come with my mother only sometimes because she often has to work on Sundays too. But when we come we meet a lot of people we know and chat with them until it closes. It's like being in Romania and it does us good, especially when outside, round and about, we hear Italians complaining about foreigners, therefore about us." (F, Romanian, 18year-old) 
"For us Peruvians, Mass is an important occasion for meeting the community. It is much more than prayer: it is gathering as a family, feeling at home. Our parents feel as though they were back in Peru, not least because they speak Spanish, which is also the language of the Mass, so everything is simpler. The feeling for us young people is of turning back to the world where we grew up but don't live there any longer." (M, Peruvian, 19-year-old)

Religion is left in the background: the reunion of compatriots, speaking the same language, the reassuring feeling that they are in a protective cocoon-this is what young people experience. This not surprising when we consider that they have spent part of their lives elsewhere and at a certain point came to Italy, a context where being a child of immigrants - a foreigner-is not easy (Ricucci, 2012), where the insertion process is interwoven with the identity-building process of their age-group. This explains why attendance at ethnic churches is most frequent in the early years in Italy and diminishes thereafter. Integration alone does not suffice to explain this divergence: it is mixed up with how these young people imagine the host society perceives them. For them too-Christian Catholics in a Catholic country par excellence-there are problems: paradoxically, they too have to deal with prejudice like their Muslim peers.

Race, an involuntary and inscriptive marker, is considered in the case of Filipinos and Peruvians to be one of the central features of identity, which separates them from Italian society. Among Romanians, their association both with Roma and with criminals risks negatively affecting their integration process: in these cases both the colour of their skin and religious belonging can be useful to avoid being noticed.

However, one of the most significant ways in which young members of the churches articulate their ethnic identity is through the appropriation of certain elements of "practised culture", that is, values and standards of their traditional morality. These values, ubiquitously invoked in their discourse about their identity, consist of a set of core traditional values-most significantly filial piety, respect for parents, familycenteredness and a work ethic.

"My Filipino values include respect for elders, and emphasis on education. Another thing I love about my Filipino culture is its family-orientedness. I adore my parents. And I really like how children take care of their parents." (F, Filipino, 20-year-old)

Compared to non-churchgoers, church members display a considerably higher degree of attachment to these values and standards of morality, which are appropriated by them as highly relevant criteria of their ethnic identity and as self-defined markers for signal- ling membership and exclusion. Indeed, the more "religious" a member is, the more embracing he/she tends to be of the traditional values espoused by his/her parents. The non-churchgoers, although they may generally observe these values, are not as strict in their interpretation of or adherence to them. Furthermore, compared with non-attenders, church attenders hold far more strictly to traditional views regarding sexual morality and gender relations, displaying a much more critical stance toward Italian (European) culture and values such as individualism and liberal sexual morality.

\section{Growing Up Feeling Themselves as "Unwelcomed"}

What does it mean to live as children of immigrants in a country where immigrants are not so welcomed? Relations of friendship, work, closeness to the Italian community and a passport are not enough to shake off the immigrant mantle. Perception means more than reality. It is the recognition theme that the Italian community-today as yesterday-may be composed of people with different somatic traits from the usual, who wear clothes which evoke faraway places (from Indian saris to the colourful robes of African women, from the chador to the Sikh turban), people believing in a divinity which is not that of the majority of the population (who, to be truthful, believe more from culture and education than from convinced and active faith) (Martino \& Ricucci, 2014).

Of course an attitude of mistrust (sometimes becoming outright hostility) has no effect on the rights which may be claimed, but may make daily life more difficult. For example, it may be more difficult to rent accommodation outside "typically immigrant" areas and neighbourhoods. It might mean not being able to find wok other than that-low paid, dirty, dangerous, heavy and socially penalizing (Ambrosini, 2005)reserved for foreigners.

It is not a simple matter to touch upon stereotypes and prejudices. The feeling that immigrants and their children are unwelcome guests is returning to the fore in these years of reduced employment opportunities and welfare benefits. Indeed, a 2014 survey carried out by Eurobarometer reported a resurgence and strengthening of dangerous stereotypes and prejudices among the Italian population: this finding confirms what another survey had already shown in 2010 (Camera dei Deputati, 2010): one-quarter (25\%) of the interviewees declared that immigrants were taking work away from Italians, and almost half (no less than 48\%) considered it right to give precedence to Italians when hiring (Pouschter, 2015).

Apart from wishful thinking and claims, what is really going on?

If entry into the community of citizens is step-bystep journey from the precarious initial insertion leading to social integration, the environments in which it is 
possible to read the characteristics of the itinerary are those of every family's daily life: home, school, work, free time (Zincone, 2009).

Yet it is clear that integration represents (or should represent, since it cannot be taken for granted) the other side of settlement, the decision to transform one's migratory project from temporary to permanent. In this sense, some social-insertion environments help to make up an information mosaic, the best possible indicator to describe the lights and shadows of integration into Italian society of those who are not (yet) citizens (Zincone, 2006). As various studies have shown, an immigrant integrates into the arrival society, but the real question is into which part of the society $s / h e$ integrates and, above all, how this process varies from one generation to the next: does the passage from first to second generations follow the "downward assimilation" logic described by Portes (1996) and Gans (2009) or does it delineate ascending mobility strategies typical of an immigrant middle class (Perlmann \& Waldinger,1997; Winthol de Wenden, 2004).

Somatic traits, first name, surname and religious affiliation "condemn" or "acquit" young people in the eyes of Italians. This is the story of some youth with a migratory background like Mohammad and Fatima, who-as they referred during an interview carried out in 2014-perceive themselves to be at risk. Even if they possess Italian passports, they are-in the common perception-foreigners. What's more, since $11 / 9$ they are foreigners and "potential terrorists", a worrying and intimidating association (Guolo, 2010, 2015). Also Jocelyne and Isabelle, two Filipinas, are trapped within their identity. At school they are considered as "custodians of traditional values and carriers of a religiosity which are not often found among young people today" (F, Filipina, 19-year-old). Then again, Roberto and Victor, two Peruvian boys, whose rapper clothes cause them to be stopped and checked by police. Peruvians attract attention because of rival gangs settling accounts. The next step is easy: all young Peruvians (both boys and girls, those involved in the game of the "boss's girlfriend" and, playing this role, they become the "bone of contention") are members of "Latino gangs" (Queirolo Palmas, 2009).

"Is there any way out? How can one react to and 'survive' daily life so conditioned by damaging stereotypes? According to one young interviewee, their patience has almost run out: "It doesn't matter who we are, what we do. The only thing that matters is what our parents do. We will always be immigrants for you. Italy should take note of the Paris banlieues and the London riots. Sooner or later we young foreigners, best in the class but judged only according to our parents' occupation, will stop being good. We will start shouting and demonstrating, making our presence felt." (M, Peruvian, 21-year-old)
Self-definition is never easy and can take place on different levels: linguistic or national, local or global, gender or generational. Using labels and categories is not a game, but often awareness of the weight (and consequences) of the use of words (one's own and others', spoken and written, enounced and read) is lacking. Sometimes this may help to create or widen fissures, even increasing the spectre of fear. Therefore the role played by the society where one grows and builds one's identity is crucial. Indeed, how young foreigners portray themselves and what identity they decide to adopt partly depends on how the society where they live sees them. The theme of immigrants' identity, especially second generations', is not ascribable to an "either-here-or-there" optional choice. It must be framed in a more general context involving traditionally different actors: 1) The individual (one may feel loss and homesickness or may try to forget and camouflage oneself); 2) The family (which has, in most cases, taken the decision to leave and makes choices about future plans, whether to become part of the new society or stay on the edges); 3) The welcoming society which, with its attitudes and policies may encourage, in migrants, disparagement or revaluation behaviour with regard to belonging and various cultural traditions. Further actors have recently come on the stage: 4) The society of (one's own or one's parents') origin, which continues to be present through transnational ties and local visits; and 5) Virtual space where cyber homelands are constructed, nostalgic sites for the first generation, a refuge for reunited adolescents, an exotic discovery for second generations (Leurs \& Ponzanesi, 2011).

What we have said hitherto brings us to the theme of identity and how the protagonists of this contribution are finding their voice, giving life to civic activism paths and combatting the image that will always see them as foreigners. It is a story of involvement and identity results with roots in their family history, which for many of the young people I met has been a history of reunion. And in the crevices of this process, transversal to all origins, attitudes mature and the insertion strategies so well described by Berry (2008) are outlined.

From the family to free-time associationism: another environment in which young people's identities are polished, sometimes being called into question. They are also the setting where-little by little-young people are beginning to express themselves, showing themselves to be autonomous subjects distinct from the immigrant stereotype of an unskilled labourer doing precarious, ill-paid, dangerous and socially penalizing jobs (Ambrosini, 2005). The web, which is what characterizes these youth, insofar as they are part of the Facebook generation or Millennials, becomes a context rich in opportunities - to show themselves, express themselves and (as happened to the children of North African emigration) to rediscover hushed up identities (Premazzi, 2014). 


\section{Conclusion}

If "Muslim youth have assumed a central, if complex, place in the politics and cultures of the global South and North" (Bayat \& Herrera, 2010, p. 5), ChristianCatholics are on the way back, especially in Europe. While in American society sociologists pay growing attention towards this specific youth group, in Europe the "fear of Islam" risks overcoming any another change. Among the novelties of the last ten years there is an increasing number of youth with a Catholic or Christian background and, as a result, the reinforcement-at least on paper-of the mainstream religion in the Italian context, or, in a broader sense, its Christian origin. The thesis is that the acculturation process under which these young people define their integration paths is stronger than their religious socialization. Broadly speaking, there is more to the lives of these youth than mere religiosity, conservative cultural ideas, and attachment to their home countries. Despite common elements of identification and cultural specificities, these youth have as much in common with their peers, both Italian and foreign, as they share among themselves. While there exist many lines of demarcation within the category of "children of immigrants" along lines of class, gender, education and cultural divides, to name a few, there are also certain common attributes that make the category of "Christian-Catholic" meaningful. But to understand what's happening we have to bear in mind that this group stands at the crossroads of three sociological areas of interest: their youth, their assimilation process and their ethnicity. Considering these three facets, their religious belonging as well as their level of religiousness assumes relevance on two planes: in their relations with both the host society and ethnic communities; and in their interaction with peers.

As an interviewee says:

“Religion is a marker. It doesn't matter if you are Muslim or Catholic. You are what your country of origin says you are. This is our life as immigrants: we cannot choose what we want to do, who we want believe in....I'm a Filipino and when teachers at school speak about me, they immediately class me as a village woman, with a mother involved in domestic services, with a high level of religiousness and strong moral values. It is the same for my Romanian friends. Is it the same for Muslims? They are treated as dangerous, or as at risk, because they belong to a dangerous community. It's funny: they don't attend a mosque or any community events." (M, Filipino, 19-year-old)

How have second-generations responded to this stereotyped environment? There have been several reactions that I witnessed during my research. Some young people have downplayed their ethnicity and their religion, and have sought to "pass" as non-Filipino/Latino or Romanians. Sometimes is very difficult: skin colour and somatic traits prevent them from hiding their ethnic origins. This is the case, of course, for Filipinos and Latinos, whose appearance and accent give them away. However, if Romanians are apparently advantaged in choosing an assimilation strategy, they share with peers the daily struggle with their families and ethnic communities.

"I attend Mass more because of solidarity with my family rather than personal enthusiasm. They expect my participation, it is like family loyalty." (F, Peruvian, 22-year-old)

"It is important to me because it is important to my parents." (M, Romanian, 23-year-old)

Some of them choose the mediation path: they go to church and show loyalty to family values, but without either commitment or conviction.

"Mass is the only time a lot of Romanians get together. Yes, you can go to a disco, but it is different: in the disco you find only Romanians who want to forget their origins." (M, Romanian, 23-year-old)

This quotation introduces another aspect: religious belonging is perceived in a social rather than a spiritual sense or in one of deep commitment. It is quite evident that for those young people inserted in the Italian context, with positive relations at school or at work, neither the parents' religion nor their religiousness is very important. Children of immigrants, at the stage of the 1.5 generation, do not express the same enthusiasm for religious icons considered vital by the first generation. They respect their parents' desire to preserve certain traditions, but do not personally speak of them with the same enthusiasm. Nevertheless, while their experience differs from the first generation, it is equally distinct from Religion Italian Style as described by Garelli (2011). The second-generation youth in these Christian Catholic congregations have charted a path that contains elements of collective expression (festivals, language, transnational ties) as well as personal agency (intense religious experience, youth organizations). Their involvement in the ethnic congregation connects them not only to families and their ethnic community here, but also to many peers in their home countries. The situation of those who have not established a positive relationship with Italian society, who have not managed to integrate, is different. They have remained anchored only to their family and community, declaring that they assiduously attend their ethnic church and its functions. In these cases, however, attachment to their community of origin seems to be dic- 
tated rather by necessity than by choice. Indeed the community, and consequently the ethnic church, are elements of support for those young people with a limited knowledge of Italian, and have not developed a mixed network of friends, but have made of contact with compatriots and activities organized within their ethnic circle the main contexts of their identity. As for the first generation, the church becomes a safe port in the storm of Italian society. They are prime candidates for a "downward assimilation" path. Foreign youth are a large and fast-growing group, and it is important to understand if and how religion can help them in the acculturation process as well as in the transition to adulthood as children of immigrants. The risk of marginalization, drug involvement, the decline in moral values, dropouts and inability to find a place in Italian society is one of the challenges both to their families and ethnic communities as well as to them. Differences with the parents' generation are to be expected. Nevertheless, the great importance the ethnic parishes continue to have for these young people shows that they are still "in between": on the one hand, for the various reasons mentioned above, they continue to follow their ethnic church and, on the other, they look for an autonomous way of belonging and religious adherence. In doing this they are both "children of their age", as young people who want to express themselves beyond the adult generation, and "children of immigrants". This marker, as happens for their Muslim peers, intervenes frequently in their daily life. Their religious belonging to Catholic or Christian Orthodox churches can help them only apparently: they feel that they are stigmatized for their saints' processions, for the length of their masses. It is a mirror image of Italians remembering a not-so-distant past, and the experience of their co-nationals abroad, stigmatized because of religiousness and their habit of carrying statues around in processions.

\section{Acknowledgments}

In this article, I benefited from discussions, ideas and findings exchanged in the framework of several research carried out at FIERI. I drown and update some parts from Ricucci (2014), a paper presented at the SSSR Conference in 2014 and at the ECER Conference in 2015. Various parts of the current article have been already published or under publishing.

\section{Conflict of Interests}

The author declares no conflict of interests.

\section{References}

Allievi, S. (2009). Conflicts over Mosques in Europe. Policy issues and trends. Brussels: NEF.
Ambrosini, M. (2005). Sociologia delle migrazioni. Bologna: II Mulino.

Bayat, A., \& Herrera, L. (2010) Introduction. Being young and Muslim in Neoliberal Times. In L. Herrera \& A. Bayat (Eds.), Being young and Muslim (pp.3-24). Oxford: Oxford University Press.

Berger, P. (1992). A far glory: The quest for faith in an age of credulity. New York, NY: The Free Press.

Berger, P., Davie, G., \& Focas, E. (2008). Religious America, secular Europe? A theme and variation. Aldershot: Ashgate.

Berry, J. (2008). Immigration, acculturation, and adaptation. Applied Psychology, 46(1), 5-34.

Bertrand, M., \& Mullainathan, S. (2004). Are Emily and Greg more employable than Lakisha and Jamal? A field experiment on labor market discrimination. American Economic Review, 94, 991-1013.

Bréchon, P. (2009). Religion: Appartenance et identité religieuse. In P. Brechon \& J. Tchernia (Eds.), La France à travers ses valeurs (pp. 227-266). Paris: Armand Colin.

Camera dei Deputati. (2010). Osservatorio sulla xenofobia e il razzismo. Rapporto annuale. Roma: Camera dei Deputati.

Caselli, M. (2008). Vite transnazionali? Peruviani e peruviane a Milano. Milan: Franco Angeli.

Cingolani, P. (2009). Rumeni d'Italia. Bologna: II Mulino.

Davie, G. (1994). Religion in Britain since 1945: Believing without belonging. Oxford and Cambridge: Blackwell.

Frisina, A. (2008). Giovani Musulmani d'Italia. Roma: Carocci.

Gans H. J. (2009). First generation decline: Downward mobility among refugees and immigrants. Ethnic and Racial Studies, 32(9), 1658-1670.

Garelli, F. (2011). Religione all'italiana. L'anima del paese messa a nudo. Bologna: II Mulino.

Garelli, F. (2013). Religion and civil society in Italy and in other Latin countries. Religions, 4(1), 1-13.

Garelli, F., Guizzardi, G., \& Pace, E. (Eds.). (2003) Un singolare pluralismo. Indagine sul pluralismo morale $e$ religioso degli italiani, Bologna: II Mulino.

Guolo, R. (2010). Identità e paura. Gli italiani e l'immigrazione. Udine: Forum Edizioni.

Guolo R. (2015). L'ultima utopia. Gli jihadisti europei. Milan: Guerini e Associati.

Hervieu-Léger, D., Garelli, F., Giner, S., Sarasa, S., Beckford, J. A., Daiber, K.-F., \& Tomka, M. (1992). La religione degli Europei. Fede, cultura religiosa e modernità in Francia, Italia, Spagna, Gran Bretagna, Germania e Ungheria. Torino: Edizioni Fondazione Giovanni Agnelli.

Hoge, D., Dinges, W. D., Johnson, M., \& Gonzales, J. L. (2001). Young adult Catholics: Religion in the culture of choice. Notre Dame, IN: University of Notre Dame Press.

ISTAT. (2015). Indicatori demografici. Stime per I'anno 2014. Roma: ISTAT. 
Leurs, K., \& Ponzanesi, S. (2011). Mediated crossroads: Youthful digital diasporas. M/C Journal, 14(2). Retrieved from http://journal.media-culture.org.au/ index.php/mcjournal/article/view/324

Martino, S., \& Ricucci, R. (2014). An increasing plural divinity. In F. Garelli (Ed.), Religion Italian style (pp. 187-206). Farnham: Ashgate.

Marzano, M., \& Pace, E. (Eds.). (2013). The many faces of Italian Catholicism in the $21^{\text {st }}$ century. Social Compass, 3.

Paerregaard, K. (2010). Peruvians dispersed: A global ethnography of migration. Lanham, MD: Lexington.

Parreñas, R. S. (2003) The care crisis in the Philippines: Children and transnational families in the new global economy. In B. Ehrenreich \& A. R. Hochschild (Eds.), Global woman: Nannies, maids, and sex workers in the new economy (pp. 39-55). New York, NY: Metropolitan.

Pérez-Agote, A. (Ed.). (2012). Portraits du catholicisme. Une comparaison européenn. Rennes: Presses Universitaires de Rennes.

Perlmann, J., \& Waldinger, R. (1997). Second generation decline? Children of immigrants, past and presentA reconsideration. International Migration Review, 31(4), 893-921.

Portes, A. (1996). The new second generation. New York, NY: Russell Sage Foundation.

Pouschter, J. (2015). Refugees stream into Europe, where they are not welcomed with open arms. Pew Research Center. Retrieved from http://www.pew research.org/fact-tank/2015/04/24/refugees-stream -into-europe-where-they-are-not-welcomed-with-op en-arms

Premazzi V. (2014). Trasnational actors or just spectators? Egyptians in Italy (PhD Dissertation). University of Milan, Milan, Italy.

Queirolo Palmas, L. (2009). Dentro le gang. Giovani, migranti e nuovi spazi pubblici. Verona: Ombre Corte.

Ricci, A. (2006). I Romeni in Italia: Immigrazione, radicamento e ritorno. Societatea Reala, 4, 25-52.
Ricucci, R. (2010). Religion and the adolescent immigrants in Italy: A way of identifying with or turning from their communities? Contemporary Journal of Religion, 25(3), 419-436.

Ricucci, R. (2012). Il liceo all'orizzonte? Studenti stranieri, famiglie e insegnanti a confronto. Mondi Migranti, 2, 123-148.

Ricucci, R. (2014). Second generations on the move. Lanham, MD: Lexington.

Tos, N., Mohler, P. P., \& Malnar, B. (Eds.) (2000). Modern society and values: A comparative analysis based on the ISSP Project. Ljubljana: University of Ljubljana and ZUMA.

Italian National Office Against Racial Discrimination. (2015). Dossier statistico immigrazione. Roma: Ed. Idos.

Vilaça, H., \& Pace, V. (Eds.). (2010). Religião em movimento: Imigrantes e diversidade religiosa em Portugal e Italia. Porto: StrategiaCriavitas.

Winthol de Wenden, C. (2004). Giovani di seconda generazione: Il caso francese. In M. Ambrosini \& S. Molina (Eds.), Seconde generazioni. Un'introduzione al futuro dell'immigrazione in Italia (pp. 107-128). Torino: Edizioni Fondazione Agnelli.

Yang, F., \& Ebaugh, H. R. (2001). Religion and ethnicity among new immigrants: The impact of majority/minority status in home and host countries. Journal for the Scientific Study of Religion, 40, 367-378.

$\mathrm{Yu}, \mathrm{T}$. (2006). Challenging the politics of the "model minority" stereotype: A case for educational equality. Equity \& Excellence in Education, 39(4), 325-333.

Zanfrini, L., \& Asis M. B. (Eds.). (2006) Orgoglio e pregiudizio. Una ricerca tra Filippine e Italia sulla transizione all'età attiva dei figli di emigrati e dei figli di immigrati. Milan: Franco Angeli.

Zincone, G. (2006). The making of policies: Immigration and immigrants in Italy. Journal of Ethnic and Migration Studies, 32(3), 347-375.

Zincone, G. (Ed.). (2009). Immigrazione: Segnali di integrazione. Bologna: II Mulino.

\section{About the Author}

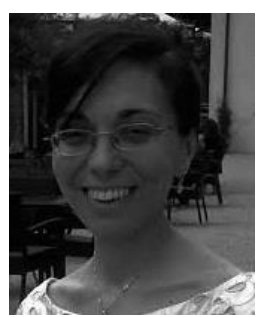

Dr. Roberta Ricucci

Roberta Ricucci is Associate Professor at the University of Turin, Department of Culture, Politics and Society, where she teaches Sociology of Inter-ethnic Relations and Sociology of Islam. She is also senior researcher at FIERI (International and European Forum of Migration Research) and member of the international networks IMISCOE (International Migration, Integration and Social Cohesion). Her recent research has generally been focussed on migration phenomena, immigrant children and second generations, investigating, especially among Muslims, their identity-building process and religiousness. 